\title{
KABAK KEMANENIN DÜNÜ BUGÜNÜ VE YARINI
}

\author{
Arslan AKYOL ${ }^{1 *}$ \\ 1: TRT Ankara Radyosu THM Saz Sanatçısı
}

\section{ÖZET}

İnsanoğlunun dünyanın bütün coğrafyalarında çok eski zamanlardan bu yana çevresindeki doğal malzemeleri kullanarak çalgı yaptığı bilinmektedir. Asya'dan Afrika' ya çok geniş bir coğrafyada görülen, doğada çeşitli formlarda bulunan su kabağının çalgı yapımında kullanılması ona çok önemli bir özellik kazandırır. Ama su kabağı en güzel forma ve sese kabak kemane adı ile Türkiye'de ulaşmıştır. Kabak kemanenin kendine has yanık bir sesi ve çalg1 tekniği vardır. Kabak Kemane Türklerin en eski ve en az değişim gösteren halk çalgılarından biridir. Kabak kemane Antalya, Isparta, Burdur ve Muğla illerini kapsayan Teke bölgesi ve civarında günümüze kadar kullanılmaya devam etmiş Yörük Türkmen müziğinin önemli çalgılarından biridir. Kemane ilk başta iki telli iken zamanla önce üç tele çıkmış, daha sonra profesyonel topluluklarda çalınmasıyla tel sayısı dörde çıkmıştır. Kemane yöresel çalgıdan ziyade tüm yörelerimizde bilinen ve çalınan bir çalgı hüviyetine bürünmüş, tıpkı diğer Türk cumhuriyetlerinde olduğu gibi ülkemizde de halk çalgıları içinde üst sıralara yerleşmiştir. Çalgı eğitimi veren yükseköğretim kurumları ile kemane yapımcılarının birlikte yapacakları çalışmalar ve eğitimlerle kemane yapımcılığının bir düzene girmesi ve milli bir çalg1 da olması gereken ortak bir görünüm alması gerekmektedir.

Anahtar kelimeler: Su kabağı, Kabak kemane, Teke Bölgesi,

\section{PAST, TODAY AND TOMORROW OF KABAK KAMANE}

\begin{abstract}
It is known that human being have made a musical instrument using nearby natural materials since ancient times in all geographies of the world. Gourd which is found in various forms in nature and is seen from Asia to Africa in a very wide geographical area is used to make a musical instrument. This gives it a very important feature. However, gourd has reached the most beautiful form and voice in Turkey with the name of "Kabak Kemane". This instrument has a unique poignant voice and a unique instrumental technique. Kabak Kemane is one of the oldest and least change public instruments of Turks. Kabak Kemane is one of the most important musical instruments of Yoruk Turkmen Music which continue to be used until today around Teke Region including Antalya, Isparta, Burdur and Muğla cities. While Kemane has initially two strings, the number of string increased three in time and then the number of strings came out four after this instrument played in professional societies. Kemane has become a well known and played instrument in all regions of Turkey rather than a regional musical instrument and also has placed in the top of our country as it is in other Turkish republics. It is necessary that making of Kemane should be in order and kemane has to a common view that should be in a national instrument through studies and education planned by higher education institutions and kemane makers.
\end{abstract}

Key words: Gourd, Kabak kemane, Teke Religion

*Yazışma yapılacak yazar: arsak55@gmail.com 


\section{GíRiş}

Laitnce adı Lagenaria siceraria olan su kabağı kabakgillerden sarmaşık türünde yetişen bir bitkidir. Yaş iken içi dolu ve çok ağır olan bu bitki kuruyup içi çekildikten sonra içi boş çok sert kabuklu çok hafif bir malzemeye dönüşür. Su kabağı sert ve suya dayanıklı gövdesi ile halkın günlük yaşantısında çeşitli şekillerde karşımıza çıkar. Suyu soğuk tutması ile termos ve sürahi, eli yakmaması ile sıcak sutaşıma kabı, hamam tası, balıkçı şamandırası, yüzme öğrenenler için cankurtaran yeleği, mutfaklarda kaşıklık, tuz kabı, pekmez kabı ve abajur gibi süs eşyası olarak da kullanılmıştır.
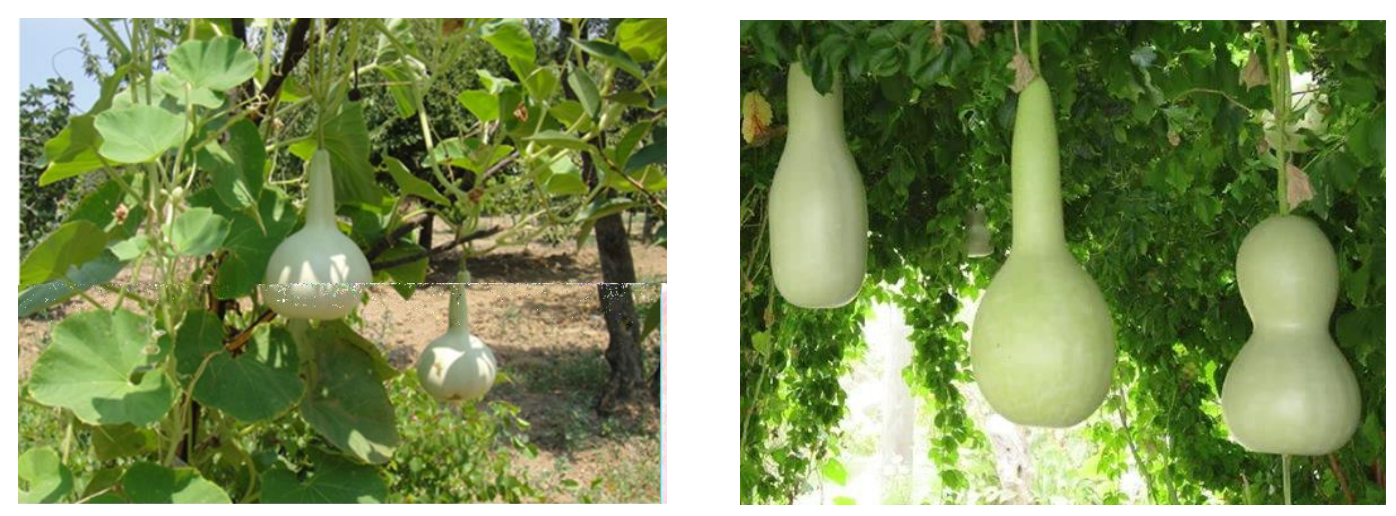

Asya'dan Afrika'ya çok geniş bir coğrafyada görülen doğada çeşitli formlarda bulunan su kabağının çalgı yapımında kullanılması ona çok önemli bir ayrıcalık kazandırır. Kurumuş çekirdeklerinin sallanarak veya dışına çeşitli ses çıkarıcı kabuklar bağlanarak marakas türü ritim çalgısı, çeşitli boyda kesilip dizilerek farklı ses çıkartan ksilefon ve bir veya daha çok tel takılarak vurmalı, mızraplı ve yaylı birçok çalgı yapılan bu bitki Hindistan başta olmak üzere dünyada birçok ülkede kullanılmıştır.
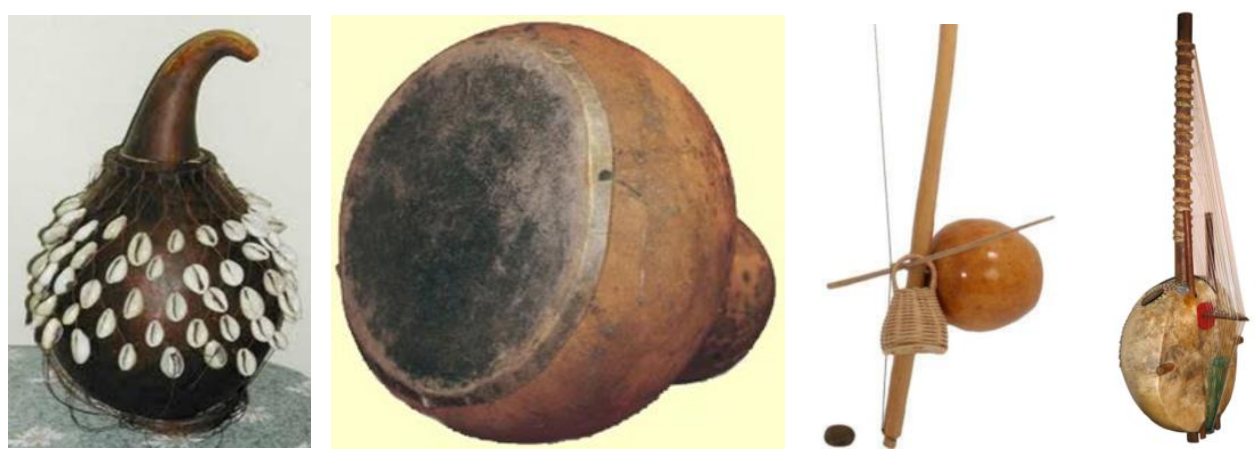

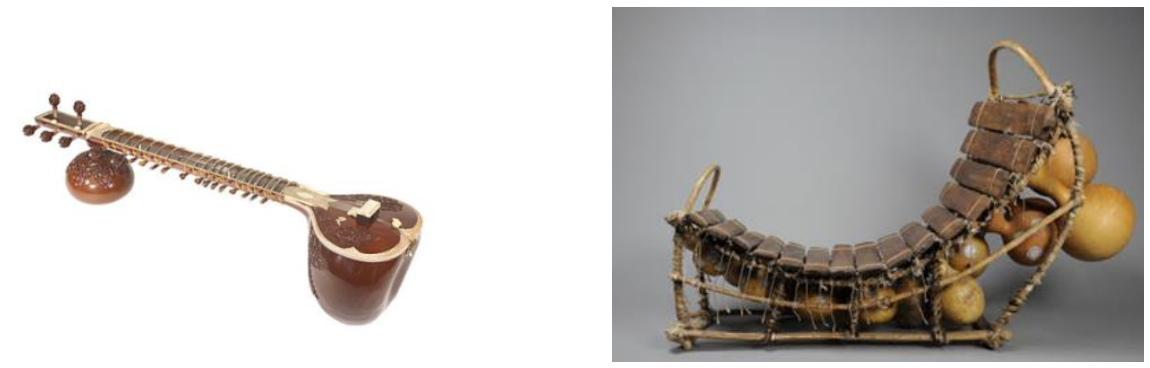

İnsanoğlu dünyanın bütün coğrafyalarında çok eski zamanlardan bu yana çevresindeki doğal malzemeleri kullanarak çalgı yaptığı bilinmektedir.

Su kabağı gibi çeşitli doğal malzemeler içi boş ses kutusu olarak (rezonatör ) bir çok yaylı çalgıda kullanılmıştır. Bu ses kutusu hindistan cevizi, kaplumbağa kabuğu, bambu ağacı gibi çeşitli malzemelerdendir. Hatta Orta Asya Tuva Türklerinde kurumuş atın kafatasından "at igil” rezonans kutusu yapılmıştır. Bu çalgılarda ise temel özelliklerden ilki yapılacak çalgının malzemelerinin doğada kolay bulunması ve kolay yapılabilmesidir.

$\mathrm{Bu}$ çalgıların ortak özelliği sesin çoğalarak çıkmasını sağlayacak çanak, (rezonans kutusu), sesin tellerle titreşimini sağlayacak ses tablası (kapak), tuşe (klavye), klavye ile gövdeyi birbirine bağlayan ve gövdenin içinden geçerek aynı zamanda tel eşiğini de bağlanıldığı metal veya ağaçtan yapılan ayak ve ses çıkarmaya yarayan yay için at kuyruğu kıllarıdır. Ses tablası yılan derisi, balık derisi, yürek zarı, koyun keçi derisindendir. Bu malzemeleri kullandıkları için Japon kokyu'sunu ve Çin erhu'sunuda bu sınıftan sayabiliriz.

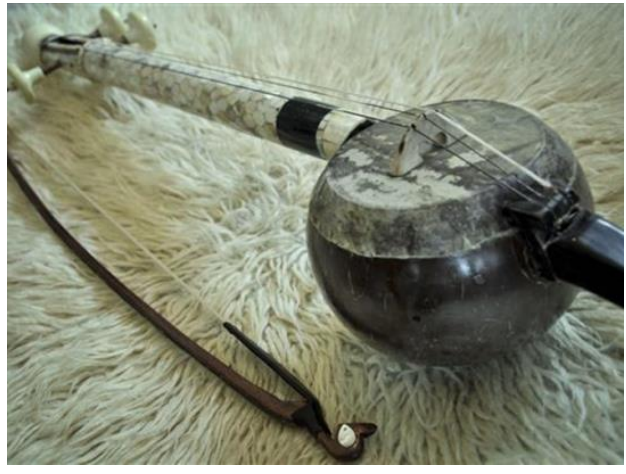

Hindistan cevizinden yapılmış rebap

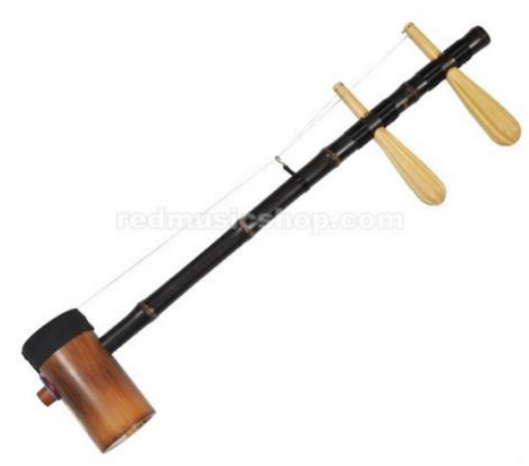

Bambudan yapılmış kokyu

\section{Iklığdan Kemaneye}

Türkler en eski silahlarından olan ok ve yayın çıkardı̆̆ı sesten esinlenerek yaylı çalgılara okla çalınan anlamında $1 \mathrm{k}=\mathrm{ok}$, okluğ, $1 \mathrm{klığ} \mathrm{adını} \mathrm{vermişlerdir.} \mathrm{Mahmut} \mathrm{Ragıp} \mathrm{Gazimihal} \mathrm{okun} \mathrm{yay}$ ( sürgeç ) anlamında Türklere özgü olduğunu ve Türklerden başka yay anlamında hiçbir dilde kullanılmadığını belirtir. Bu isim zamanla yerini yine yay anlamına gelen Farsça Keman kelimesine ordan da kemaneye dönüşmüştür. $\left({ }^{1}\right)$

\footnotetext{
${ }^{1}$ Mahmut R. Gazimihal; Asya ve Anadolu Kaynaklarında IKLIĞ Ses ve tel birliği yayınları. Ankara 1958
} 
Iklığın ilk defa en geniş tarifi 15. yy da Ahmetoğlu Şükrullah '1n Edvar-1 Musiki adlı eserinde görmekteyiz. Bir çok çalgının yapım tekniğinin anlatıldığı bu eserde 17. fasılda 1klığın iki telli yarım küre gövdeye ( tasa ) geyik derisi kapaklı ve sapınında badem ağacından veya abanoz ağacından yapılması gerektiği tarif edilir. Bu eserde yay için en az otuz atkılı takılması ve yay içinde gayet sert ağaç kullanılması gerektiğini belirtilir. Eserde Iklığın akordu beşli aralık olup $1 \mathrm{klık}$ ve yayının resmi de bulunmaktadır. $\left({ }^{2}\right)$

Iklığ 16 yy. da Sofyalı Nimetullah efendinin Farsça Türkçe lügatında ve 16. yy sonlarında İnegöllü mustafa nın düzenlediği Cami-ül-Fürs lügatında Rebap ve kemançe kelimelerinin karşılığı olarak yer almıştır. Evliya çelebi de seyahatnamesinde 1 klığa yer vermiştir. Anadolu da 1klıkçı adında köyler bulunması bu çalgının zamanında ne kadar yaygın olduğunun bir göstergesidir.

Iklığ; Anadolu'da Dızdır, Çağana, Gıvgıv, Gıygı, Gıygıy, Gıygırak, Gangili ve Hegit'i gibi farklı adlarla günümüze kadar gelmiştir. Bu gün ise Iklığ adı sadece iki telli çalgıda anılırken üç ve dört telli çeşitleri kemane adı ile kullanılmaktadır. Yarım küre gövdeli, deri kapaklı, dize konularak çalınan yaylı çalgılar ailesi içinde bulunan çalgıların tamamı ıklığ ailesi olarak ta tanımlanabilir.

Türklerin en eski ve en az değişim gösteren halk çalgılarından biri olan kabak kemane akraba çalgılarda su kabağından ses kutusu yerini ağaç çanağa bırakmıştır. Yapısal özelliği ve çalma biçimiyle aynı olan bu çalgıyı Türkmenistan' da ve Uygurlarda Gıcek- Gıcak,Özbekistan,

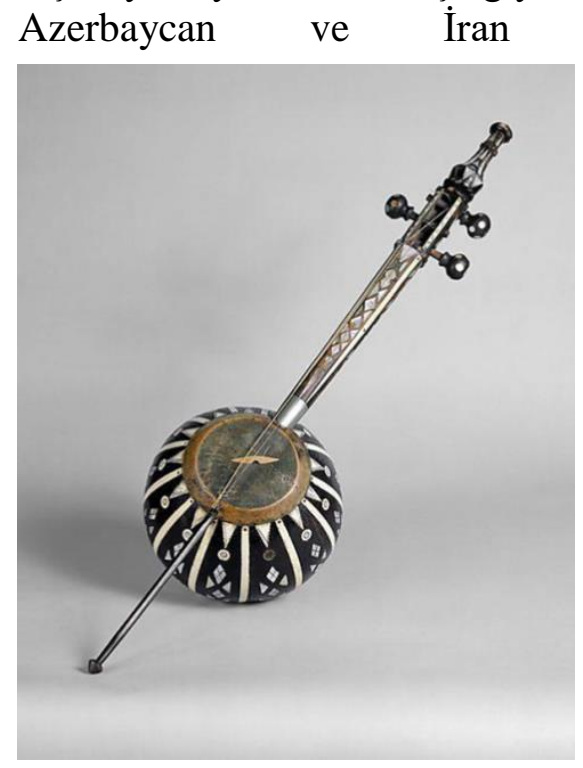

üç telli kemança

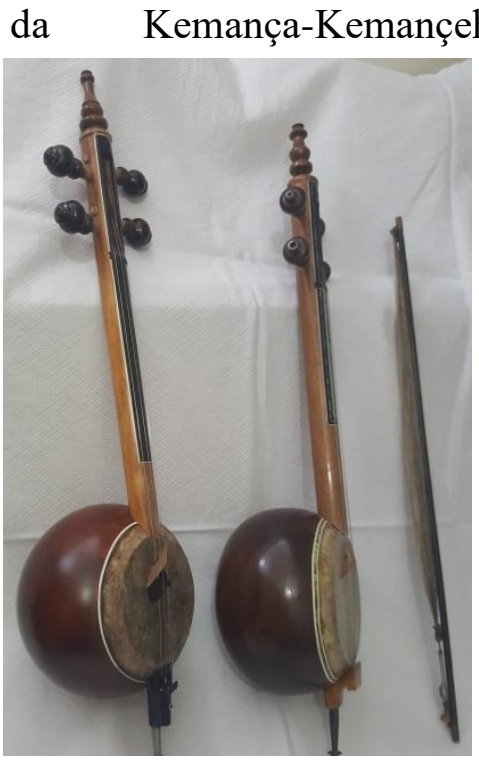

dört telli kemançalar

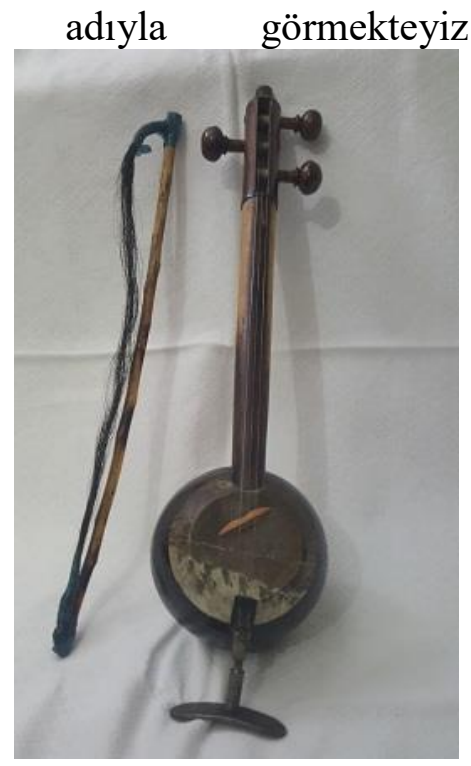

üç telli Türkmen gıceği

Rebap 1 klı̆̆ ailesi içinde uzun sapı ve Hindistan cevizi teknesi ile farklı bir yere sahiptir. Selçuklu ve Osmanlı dönemlerinde revaçta olan bu çalgı Güney Asya'dan Afrika' ya çok geniş bir coğrafyada görülmektedir. Önceleri telleri at kuyruğundan olan bu çalgıda günümüzde bağırsak ve ipek teller kullanılmaktadır. Uzun sapından dolayı birinci tel üzerinde ezgi icra edilmekte ikinci ve üçüncü teller dem teli olarak kullanılmaktadır. Osmanlı minyatürlerinde teknesi ağaç yaprak dilimlerden yapılmış çeşitleri de yer almaktadır. Bu gün halen tasavvuf musikisi çalgısı olarak varlığını devam ettirmektedir.

\footnotetext{
2 Bardakçı,Murat, Ahmed Oğlu Şükrullah Şükrulla’ın Risalesi ve 15.yüzyıl Şark Musikisi Nazariyatı Pan Yayınları, İstanbul, 2011
} 

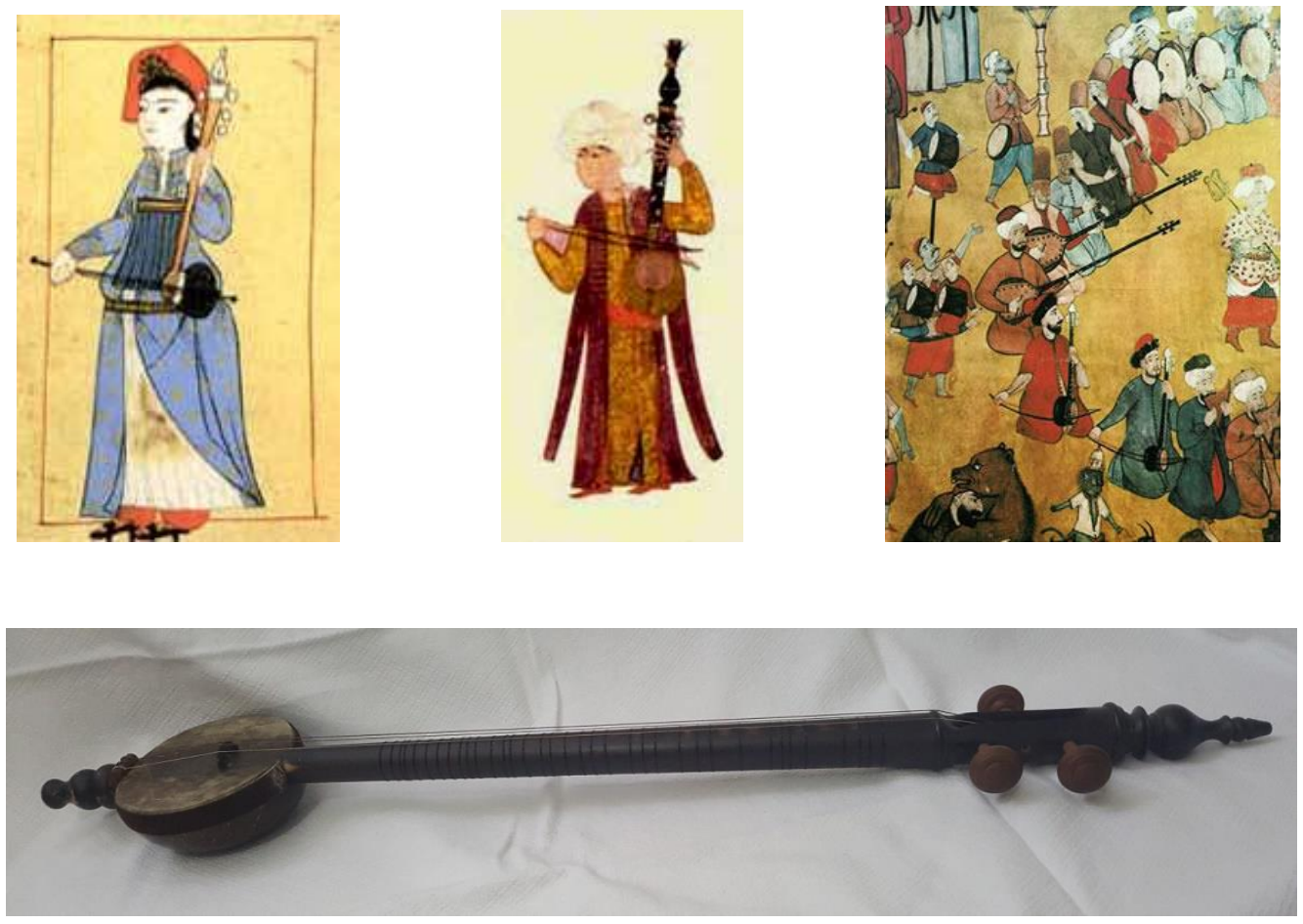

\section{Ülkemizde kemane yapımcılığı}

Kemane önceleri Anadolu'nun tüm bölgelerinde görülürken Keman çalgısının Anadolu'ya girmesiyle yerini kemana bırakmıştır. Keman önceleri kemanenin tutuş ve çalım biçimiyle kullanılır olmuştur. Bu günde hala Anadolu'da kemaneyi dize koyarak kemane gibi çalma geleneği mevcuttur.

Kabak kemane Antalya, Isparta, Burdur ve Muğla illerini kapsayan Teke bölgesi ve civarında günümüze kadar kullanılmaya devam etmiş Yörük Türkmen müziğinin önemli çalgılarından biridir. $\mathrm{Bu}$ nedenle tespit edebildiğimiz ilk kabak kemane yapımcıları da bu bölgeden çıkmıştır. Özellikle Türkmenistan'da kullanılan gıcek ile bu bölgede kullanılan kemanenin boyut ve çalma biçimi dikkat çekicidir. Bu bölge dışında Güneydoğu Anadolu Bölgesi'nde Mardin Siirt Batman gibi illerde kemanenin daha yassı gövdeli ve genellikle ağaçtan yapılan üç telli kemanelerde hala kullanılmaktadır. Kabak kemanenin radyolarda THM topluluklarında çalınması ile birlikte Teke bölgesi haricinde unutulmaya başlanan bu çalgımızı yeniden tanınır yapmıştır. Bu durum yurdun çeşitli bölgelerinde kemane imalatçıları ortaya çıkmasına neden olmuştur. İstanbul Türk Müziği Devlet Konservatuvarı çalgı yapım bölümü kuruluncaya dek kemane geleneksel yöntemlerle basit el aletleri ile iptidai bir şekilde yapılmaya devam edilmiştir. Bu dönem yapılan kemanelerde ne tekne ne de klavye boyu standart değildir. Kemane yapımcılarının incelediğimizde ise bölgesi kemane yapımcılarının birçoğunun kendi çaldıkları çalgıyı kendileri için yapmış oldukları görülmektedir. ${ }^{3}$

Kemane yapımcılarının büyük çoğunluğu bağlama, kemençe gibi çeşitli çalgıların yapım ustası olmalarının yanında istek olduğunda da kemane de yapmışlardır. Bazı kemane yapımcıları ise amatör başladıkları kemane yapımcılığına talebin artması ile profesyonelliğe yönelerek sadece kabak kemane yapan usta haline gelmişlerdir. Günümüzde sadece sadece kabak kemane yapıp bir atölye işleten usta çok nadir bulunmaktadır..

\footnotetext{
${ }^{3}$ Değirmenci T., Eren B, Burdur'da kabak kemane yapımcılığı, ulusal pazarda yeri 1.Burdur sempozyumu bildiriler. Burdur 2007
} 
İstanbul Teknik Üniversitesi Devlet Türk Müziği Konservatuvarı Çalg1 Yapım Bölümü kurucusu olan Çafer Açın kemanenin standart ölçülerini ortaya çıkarmıştır. Ancak kemanenin standartlaşabilmesi için su kabağından vazgeçilmesi ve ağaç dilimlerden bükülerek yapılması gerektiğini ifade etmiştir. ${ }^{4}$

Cafer Açın standart ölçüler ortaya koymasına rağmen halen kemane yapımcıları kemaneyi kendine göre ölçülendirip burguluğundan klavyesine kadar kendi beğenisine göre yapmaktadır. Türk dünyasında görülen çalgıdaki standart görüntü maalesef bizde oluşturulamamıştır. Bir çok çalgı yapımcısı becerilerini kemanenin işlevinden çok süslemeciliğine önem vermişlerdir. CNC lazer tezgahlar gibi gelişen teknolojik aletleri kullanmalarına rağmen klavye üzerine yazı veya resim yapmaktan öte geçememişlerdir.

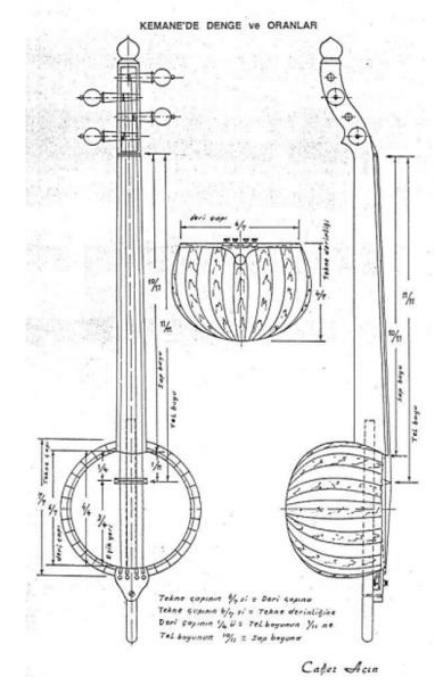

Kemanenin Cafer Açın tarafından çıkarılan ölçüleri

Teknesi ağaçtan yapılan kemaneler su kabağının içinde olan köpüksü maddenin yerini tutmadığından dolayı su kabağından yapılan kemanelerin tınısını verememiştir. $\mathrm{Bu}$ da ağaç kemanelerin kullanıcılar tarafından beğenilmemesine yol açmıştır. Çalgı yapımcılarının ağaç kemane den kabak kemane tınısı alma çalışmaları halen devam etmektedir. Çalgının gövdesi ister kabaktan yapılsın ister ağaçtan yapılsın, adı ister kemança ister gıcak olsun, akraba çalgıları 'kemane', olarak adlandırabiliriz.

Su kabağının kemane yapılmasında halen tercih edilmesi aynı aileden olan Orta Asya Türk dünyası çalgıları içinde Kabak Kemane'nin Türkiye' ye özgü bir çalgı konumuna gelmesini sağlamıştır. Üç telli kemane halen teke yöresinde geleneksel icracılar tarafından kullanılmaktadır. Kemanenin radyolarda kullanılması ile birlikte tel sayısı dörde çıkmış ve profesyoneller tarafında dört telli kemane kabul görmüş̧ür. Çeşitli yapımcılar tarafından beş , altı ve daha fazla telli kemanelerde denenmiştir. Beş telli kemane bir oktav pesten çalınan ezginin daha rahat çalınmasını sağlamıştır. İstanbul' da Arslan Hazreti beş telli kemança yapıp çalmaktadır. Daha önce bir çok yapımcının yaptığı altı telli kemane asıl ününe Cafer Nazlıbaş'ın icrasıyla kavuşmuştur.

Kemane ilk başta iki telli olan bu çalgı türü zamanla önce üç tele çıkmış, daha sonra profesyonel topluluklarda çalınmasıyla tel sayısı dörde çıkmıştır. Günümüzde iki telli kemane

\footnotetext{
${ }^{4}$ Açın,Yücel Açın, Yücel., Türk Halk Müziği Yaylı Sazlarından Kemane'nin Doğuşu, Yapımı, ve Ailesinin Oluşması İstanbul Teknik Üniversitesi Sosyal Bilimler Enstitüsü Basılmamış yüksek lisans tezi. İstanbul,1993
} 
1klı̆̆ adıyla halen yaşadığı görülmektedir. Iklı̆ sanatçısı Emin Kök halen Antalyada yaşamakta ve bu çalgıyı ilerlemiş yaşına rağmen ustalıkla icra etmeye devam etmektedir. $\mathrm{Bu}$ çalg1 sap kısmı standart kemanelerden daha kalın orta asya kopuzlarını andırmakta ve bağırsak tel kullanılmaktadır. Kemane sanatçısı Uğur Önür Antalya serikte parçalanmış olduğu 1klığı kemane yapım ustalarından Tevfik Gülten 'le birlikte restore ederek ülkemizi Ankara Devlet Türk Dünyası Müzik Topluluğu şefi İrfan Gürdal ile birlikte Kazakistan Astana'da temsil etmiştir.

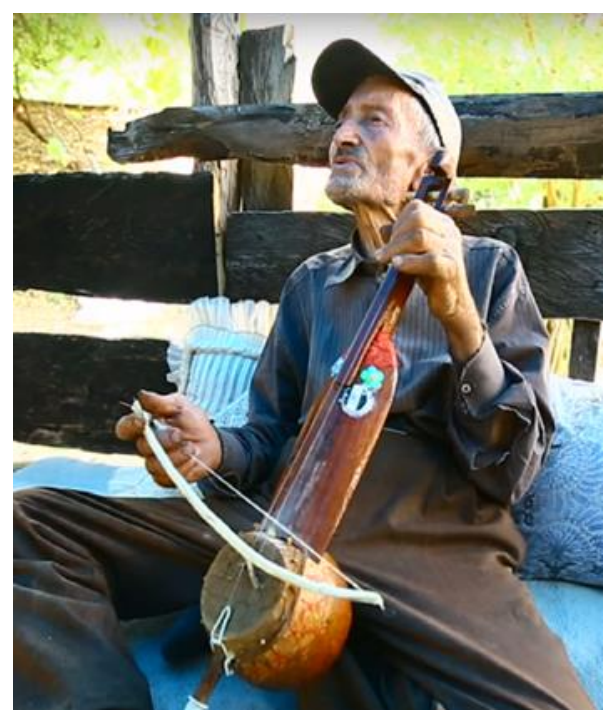

İki telli ıklığıyla Antalya Serik’li Emin Kök

\section{Kabak kemane yapımı}

Kemane yapmak için öncelikle iyi kurumuş gövde çap1 $14-16 \mathrm{~cm}$ düzgün formda bir su kabağı seçilir. Su kabağının küre şeklindeki gövdesi yaklaşık 3te bir oranında kesilir ve bir gün suda bekletilerek dış kabuk zarı temizlenir. Çap 9 ila $11 \mathrm{~cm}$ arasındaki ağız kısmına deri gerilmesiyle ses tablası elde edilir. Bu deri genellikle büyük baş hayvanlarının yüreğini saran yürek zarıdır. Bunun dışında balık derisi ve kuzu ya da oğlak derisi gibi çeşitli hayvan derileri kullanılmaktadır.

$30 \mathrm{~cm}$ den oluşan klavye akça ağaç, gürgen ve ceviz gibi sert ağaçlardan yapılır Gövdeden geçen metal ya da ağaç çubukla gövdeyle klavyeyi birbirine bağlanır. Bu çubuk gövdeden sonra $10 \mathrm{~cm}$ uzun bırakılarak kemanenin diz üzerinde durmasını sağlayan ayak kısmı oluşturulur. Bu ayağın gövde tarafına alt eşik bağlanır. Gövdenin verniklenmesi esnasında hava koşullarından etkilenmesi için deriye de çok ince bir kat vernik sürülür. Kuruduktan sonra tellerin üzerine geleceği tel eşik ( Köprü ) yapılır. Bu eşik yaklaşık $4 \mathrm{~cm}$ uzunluğunda ve yarım cm genişliğinde iki ayaklı bir köprü şeklindedir. Bu köprü iki ucundan $1 \mathrm{~cm}$ kare çapındaki ayaklarla deriye basar.Bu köprü Azerbaycan kemançalarında bam tellerin bastığ tarafi daha iyi bas ses elde etmek için deri kapağın ortasına doğru $2 \mathrm{~cm}$ eğri konulur. 


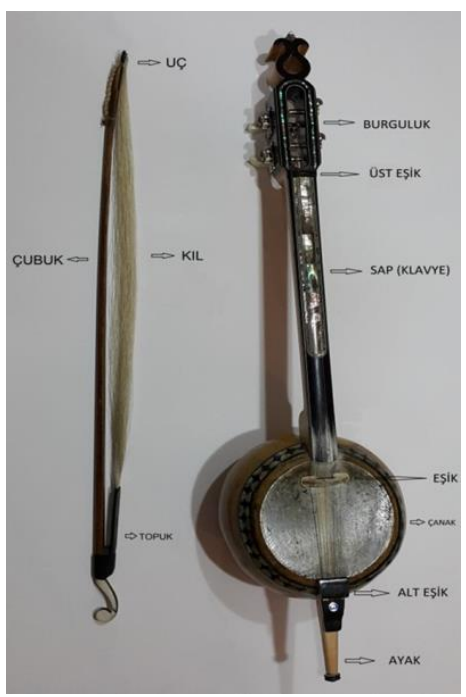

kemanenin bölümleri

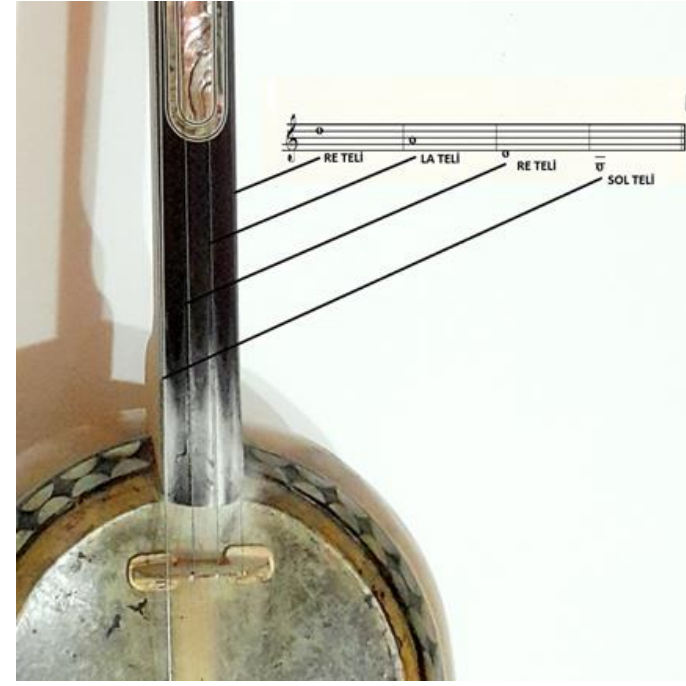

kemane tellerinin akordu

Kullanılan teller kullanıcılara göre değişmesine rağmen genellikle Tel kalınlıklarını şöyle siralanmaktadir:

1. tel 020 veya 022 madeni tel

2. tel 030 veya 032 madeni tel

3. tel 042 veya 045 sirma tel veya ince bam tel

4. tel 055 veya 065 sırma tel ( kalın bam tel )den oluşur.

Bam teller tıraşlanmış olması daha makbuldür. Ayrıca akustik gitar tellerinin 020 ve 030 numaraları ile keman telinin 3 ve 4 numaraları da kullanılmaktadır.

\section{Kemanede yapılan çeşitli akort şekilleri}

Çalınan ezginin daha doyurucu gelmesi için bağlamada daha iyi tını elde etmek için yapılan farklı düzenler kemane için yapılmaktadır. Azerbaycan'da daha ziyade çalınan ezginin karar sesini güçlendirmek amacıyla makama göre de akort yapıldı ğı görülmektedir. Kemanede daha ziyade farklı tonlarda çalınırken mi notasının güçlü olduğu yerlerde 1. parmağın mi notasına gelmesi için yapılmaktadır. Ayrıca eşlik edilen ezginin veya sanatçının tonuna göre farklı akortlar yapılmaktadır.

Kemanenin halk arasında akordu 4-5-4 iken eğitimde daha ziyade geleneksel Türk sanat müziği keman akordu etkisiyle ve bir ses daha kazanabilmek amaciyla 4-5-5 aralıklarla akot yapılmaktadir.

Azerbaycan kemançasında kullanılan 5-4-5 sisteminde daha ziyade erkek solistlere eşlik etmek amaciyla kullanılmaktadır. 
Kemane farklı tonlarda akort edilmesine rağmen tel isimleri aynı adlandırılır Buna göre;

Piyonaya göre akortlanır

Adlandirilır

1. tel: fa

$\operatorname{Re}$

2. tel: do

$\mathrm{La}$

3. tel: Fa (1.tele göre bir oktav pes)

$\operatorname{Re}$

4. tel: Do (2.tele göre bir oktav pes) veya Si bemol

La veya Sol

\section{Tespit edebildiğimiz kemane ve kemança yapımcıları;}

Necmi Berbergil ( İstanbul )

Mehmet Coşkun ( İzmir )

Şükrü Acar ( Burdur )

Ahmet Çetin ( Burdur )

İbrahim özleyen ( Burdur )

Tahsin Yarar ( Burdur )

Veyis Yeğin ( İzmir )

İrfan Alkur ( İzmir )

Ahmet Akın (Samsun )

Halil Çelik (Uşak )

Galip Güvençoğlu ( Eskişehir )

Teyfik Gülten ( Antalya )

Mehmet Gürdal ( Isparta )

Hüseyin Ayanlar ( Antalya )

Erkan Ketenci ( Ankara )

Arslan Akyol ( Ankara )

Arslan Hazreti (İstanbul )

Ali Y1lmaz ( Iklık Antalya Manavgat)

Kadri Dilmen ( Zonguldak )

\section{Geleneksel çalgı ailesi oluşumu fikri}

Dünyada geleneksel çalgıların senfonik orkestralar gibi oluşturulmasına gittikçe önem verilmektedir. Prof. Dr. Bahattin Ögel Türk Kültür Tarihine giriş adlı eserinde Vertkov' un 1980 yılında yayınladığı Sovyetler Birliği Halklarının Çalgıları Atlası kitabında Türklere özgü çalgılarda da bir çalgı ailesi oluşturma fikrinden bahsetmektedir. 


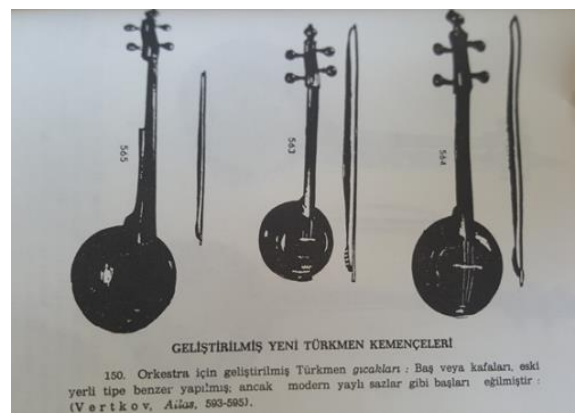

Orkestra için geliştirilmiş Türkmen gıcakları

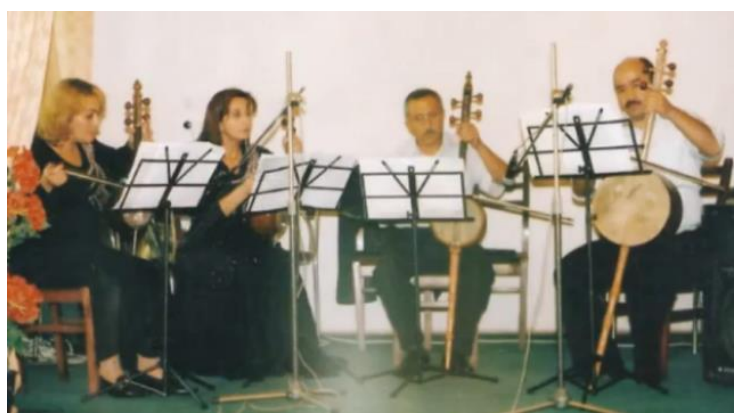

Azerbaycan kemanca dörtlüsü

Kemanenin yaygınlaşması sonucu çeşitli tonlarda icra amacıyla farklı ölçülerde kabak kemanelere ihtiyaç doğmuştur. Kemane, alto kemane ve bas kemane olmak üzere kemane ailesi ilk defa İTÜ Devlet Türk Müziği Konservatuvarı çalgı yapım bölümü başkanı Cafer Açın tarafından yapılmıştır.

$\mathrm{Bu}$ okuldan mezun olan Çafer Açın'ın öğrencisi Veyis Yeğin'nin öncülüğünde Ege Üniversitesi çalgı yapım bölümünde kemane ailesi yapılmıştır. Kemanede standartlaşmaya geçebilmek amacıyla kemaneyi bir bitki olan ve hiç bir standarda girmeyen su kabağı yerine ağaç yaprak dilimlerden yapmak tercih edilmiştir. Bunda kemane ailesi oluşturacak form ve büyüklükte su kabağının temin edilemeyişinin de etkisi vardır.

Gerek İTÜ TMDK gerek Ege TMDK ve Arslan Akyol kemane ailesi kurarken çalgıların tonlarını elde etmede gerekli olan tel kalınlığına ve çalgı boyutuna keman ailesinde kullanılan ölçüleri kullanarak standartlaşmaya gitmişlerdir. Çeşitli kemane yapımcıları sadece tel kalınlığını ve gövdeyi büyütürek tel boyu ve sap boyu ile oynamadan alto ve bas kemane yaptıklarını ifade etmişlerdir.

Arslan Akyol Erzurum'da 1989 da viyola boyutlarında alto kemaneyi ve 1992 de viyolonsel boyutlarında bas kemaneyi yapmıştır. Tenor ve alto kemanelerde uygun boyutta su kabağ bulunmuş, ancak bas kemanede (çello boyutundaki) ağaç yaprak dilimlerden yapmak zorunda kalmıştır. $\mathrm{Bu}$ çalgılar halen radyo ve TV de yayınlanan halk müziği programlarında kullanmaktadır.

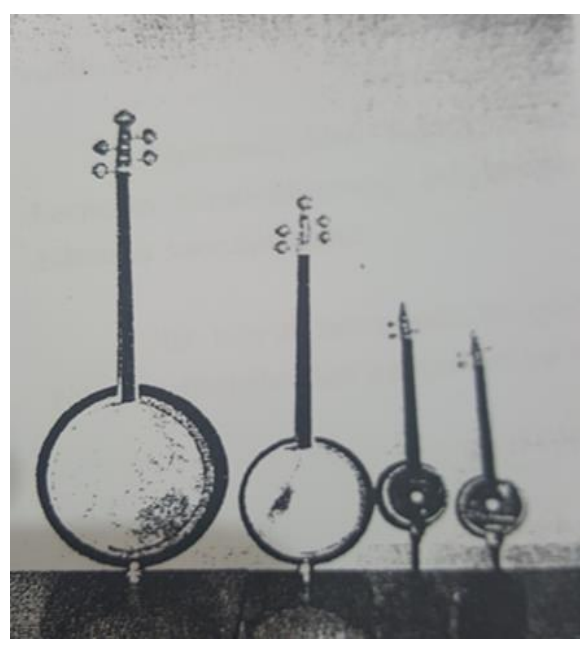

Çafer Açın tarafından yapılan kemane ailesi

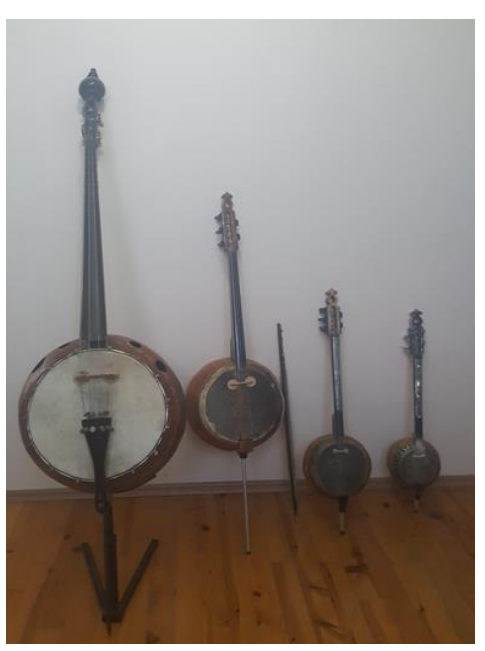

Arslan Akyol tarafindan yapılan kemane ailesi 
Uşaklı kemane yapımcısı Halil Çelik kabaktan çeşitli boyutlarda kemaneler yapmış basname gibi çeşitli isimler vermiştir.

Dize konulabilecek boyutta olan soprano ve tenor kemane için mevcut kemane eğitimi yeterli olabilecekken alto ve bas ( kaba ) kemane için yeniden bir metot hazırlamak gerekmektedir.

Viyola ve viyolonsel çalanların rahatlıkla çalabileceği ölçüde ve tonda olması mevcut viyola ve viyolonsel metotlarına Türk Halk Müziği dizilerinden oluşan alıştırmalar eklenmesiyle rahatlıkla kullanılır hale gelecektir. Günümüzde bu uygulama Türk Musikisi Konservatuvarlarında zaten uygulanmaktadır.

\section{TRT ve Kültür Bakanlığına bağlı topluluklarda Kemanenin kullanılması}

Kabak kemane TRT de ilk olarak 1969 yılında İzmir Radyosunda Salih Urhan 1970 yılından itibaren de İstanbul Radyosunda Yalçın Özsoy ve Ankara radyosunda Emin Aldemir tarafindan sadece yöresel ezgilerde çalınmasıyla halk müziği topluluklarında yer almaya başlamıştır. Daha sonra ise halk müziği korolarının değişmez bir sazı haline gelerek yöre gözetmeksizin her tür ezgide kullanılmaya başlanmıştır.

Kemane Devlet Radyolarında Yurttan sesleri topluluklarının kurulmasından sonra ilk defa kabak kemaneye ilgisi olan bağlama çalan sanatçılar tarafından çalınmaya başlandı. Kabak kemane kadrosuyla TRT ye ilk defa sanatçı alımı 1981 de gerçekleşti.

1986 yılında Kültür Bakanlığı Ankara Devlet Türk Halk Müziği kuruldu. Kemane sanatçılarının alındığı yıllar ve çalıştıkları radyo ve kuruma göre bir listesini yaptık;

\section{Kuşak Sanatçılar ( 1970 )}

Ankara Radyosunda Emin Aldemir

İzmir Radyosunda Salih Urhan

İstanbul Radyosunda Yalçın Özsoy

\section{Kuşağı Sanatçıları :}

Hüsnü Aydoğdu

Fatih Gürgün

İhsan Mendeş

İsmet Egeli

\section{Kuşağı Sanatçıları :}

Bayram Salman

Bayram Bağdatl

Ahmet Yakar 
1987 Kuşağı Sanatçıları :

Ersin Baykal

Arslan Akyol

2015 Kuşağı Sanatçıları :

Burhan Elmas

Uğur Önür

Cafer Nazlıbaş

TRT kurumunda sözleşmeli ( istisna akitli ) çalışmış kemane sanatçıları

Özgür çelik

Göktuğ çelik

Ozan Bircan

Metin Efe

Cengiz Sağlam

Murat Vural

Ercan Köktürk

Kültür Bakanlığına bağlı Devlet Halk Müziği Koro ve topluluklarındaki kadrolu kemane kemança sanatçıları

İrfan Gürdal

Mehmet Çıracı

Mustafa Dilek Gül

Mehmet Torun

Ertuğrul Eraslan

Muhsin Gurbani

Aydın Özdemir

Hüseyin Yalçın

Mehmet Akif Teke

Engin Demirtaş

Kabak kemane sanatçılarının tamamının kemane dışında bağlama çaldığını tespit ettik. Birçok sanatçı ise bağlama dışında keman, viyola, viyolonsel, kemençe, tırnak kemane gibi yaylı çalgıları da çalmaktadırlar. Yine birçoğunun bağlama dışında üç telli cura, tar, cümbüş, gibi bir çok mızraplı çalgıyı da ustalıkla çaldıkları görülmektedir. 


\section{Ülkemizde eğitim tarihi ve uygulamaları}

3 Mart 1976 da eğitime başlayan İstanbul Türk Musikisi Devlet Konservatuvarı'nda 1982 yılında İstanbul Teknik Üniversitesi ne bağlanmıştır), o yıllar da kemane çalan sanatçının çok az olması, bağlama yanında kemane de çalabilen sanatçılardan öğretmen olarak faydalanılması yoluna gidilmiştir. ${ }^{5}$ Konservatuvarın ilk kemane hocası İstanbul Radyosu Türk Halk Müziği Topluluğu sanatçısı Yalçın Özsoy ' dur. Bu dönemde kemane eğitiminde belirli bir eğitim programı olmadığı ve bir meşk anlayışının hakim olduğu görülmektedir.

Çalgısında iyi bir seviyeye gelen öğrenciler alt sınıflarda kemane eğitimi vermeye başlamış ve bu öğrenciler mezun olunca da eğitimciliğe devam etmişlerdir. Bu öğrencilerden Nurhan Akdemir araştırma görevlisi kadrosu ile göreve başlamış sınıf arkadaşı TRT İstanbul Radyosu ilk kadrolu kemane sanatçısı olan Fatih Gürgün ile kemane dersleri devam etmiştir. Fatih Gürgün daha okuldan mezun olmadan 1979 da TRT İstanbul radyosunda kemane sanatçısı olarak görev yapmaya başlamıştır. Daha sonra Ersin Baykal ve sınıf arkadaşı olan Ferhan Yeprem ile birlikte önce öğrencilik yıllarında daha sonra da araştırma görevlisi olarak kemane eğitimi vermişlerdir.

1984 te eğitime başlayan Ege Üniversitesi Türk Musikisi Devlet Konservatuvarı'nda TRT İzmir radyosu Kabak kemane sanatçısı Salih Urhan kemane dersleri vermiş, emekli oluncaya kadar da hem radyodaki hem de Konservatuvardaki görevine devam etmiştir.

$\mathrm{Bu}$ güne gelindiğinde Üniversitelerde konservatuvar mezunu akademisyenler tarafindan dersler verilmektedir.

\section{Kemane Eğitimi Veren Yüksek Öğretim Kurumları}

İstanbul Teknik Üniversitesi Türk Musikisi Devlet Konservatuvarı'nda Ferhan Yeprem (Kemane), Kadir Verim (Kemança)

Ege Üniversitesi Türk Musikisi Devlet Konservatuvarı'nda Özgür Çelik ve Aycan Özdemir, Gaziantep Üniversitesi Türk Musikisi Devlet Konservatuvarı'nda Gültekin Şener,

Afyon Kocatepe Üniversitesi Türk Musikisi Devlet Konservatuvarı'nda Ali Haytap Kulaboğa, Ordu Üniversitesi Türk Musikisi Devlet Konservatuvarı'nda Timur Eşigül,

Antalya Akdeniz Üniversite Deniz Dinçel

Koceli Üniversitesi 'nde Metin Efe

Malatya İnönü üniversitesi Ali Tohumcu

Tokat Gaziosmanpaşa Üniversitesi'nde Bahadırcan Demirkayalı

Haliç Üniversitesi Türk Musikisi Devlet Konservatuvarı'nda Ozan Bircan,

Kars Kafkas Üniversitesi Devlet Konservatuvarı'nda Prof. Doktor Rafig İmrani başkanlığında Kemança eğitimi verilmektedir.

Bu konservatuvarlardaki öğretmenlerle yaptığımız görüşmelerde eğitimin kendi kişisel ders notları ile devam ettiklerini ve basılı veya hazırlanmış belirli bir metot bulunmadığını

\footnotetext{
${ }^{5}$ Paşmakçı Yücel İstanbul Teknik Üniversitesi Türk Müziği Devlet Konservatuvarı ilk yönetim kurulu üyesi , Haliç Üniversitesi Konservatuvarı öğretim Görevlisi ile kişisel görüşme ) (16. ocak 2015.
} 
belirtmişlerdir. Konservatuvarlar arası bir iletişimde olmadıkları gibi ortak bir müfredatları da yoktur. Azerbaycan'da basılan Kemança metodu ve diğer batı müziği keman metotları en çok yararlandıkları kaynaklar olmaktadır. Mezun olan öğrenciler yüksek lisans tezlerinde kemane konulu çalışmalar yapmışlardır. Ancak Kemane eğitimi ile ilgili yükssek lisan tezleri dışında akademik bir çalışma günümüze kadar yapılmamıştır.

Salih Urhan'ın yazdığı kemane metodu da ders kitabı olarak kendisinin yanında bu okullarda metod veya kaynak olarak kullanılmaktadır. Konservatuvarların hepsinde eğitimin aşamaları aynı olmakla birlikte okullara göre akort farklılığ 1 , kemaneyi tutuş pozisyonu, eğitime başlangıç biçimi gibi farklılıklar ilk göze batanlardır. Ayrıca kemane ölçülerinde de bir standart ölçü aranmadı̆̆ını gözlemledik.

\section{Kemane üzerine yapılan tezler}

Türk müziği eğitimi veren konservatuvarlar ve yüksek öğretim kurumlarıyla birlikte Türk Müziği ile ilgili akademik, tez araştırma makalelerinde artmasını da sağlamıştır.Bunlardan tespit edebildiklerimizi şunlardır:

Ersin Baykal, 1985, Kemanede yeni yapım teknikleri, İstanbul Teknik Üniversitesi, Sosyal Bilimler Enstitüsü Yüksek lisans tezi,

S.Yücel Açın, 1993Türk Halk Müziği Yaylı Sazlarından Kemane 'nin Doğuişu, Yapımı ve Ailesinin Oluşması İstanbul Teknik Üniversitesi, Sosyal Bilimler Enstitüsü Yüksek lisans tezi,

Gültekin Şener, 1994,Türk Halk Müziği Yaylı sazlarında Kemane'nin yapısı - Pozisyon problemleri ve Eğitimi, İstanbul Teknik Üniversitesi, Sosyal Bilimler Enstitüsü Yüksek lisans tezi,

Ali Haykad Kulaboğa, 2007,Ege bölgesi türkülerinin Afyon Kocatepe Üniversitesi Devlet Konservatuvarı Türk Halk Müziği Bölümünde verilmekte olan Kabak Kemane eğitimine uygulanabilirliği ve bu çalışmanın uzmanlar tarafından değerlendirilmesi, Afyon Kocatepe Üniversitesi Sosyal Bilimler Enstitüsü Yüksek lisans tezi,

Alper Tunga Özcan , 2008, Iklığ - Rebap - Kemençe - Keman yaylı çalgı evrimi ve müziği Mersin Üniversitesi Sosyal Bilimler Enstitüsü

Özgür Çelik 2009 Türk dünyasında üç yaylı çalgı: Kılkobız, kamança ve kabak kemane üzerinde bir inceleme Ege Üniversitesi Sosyal Bilimler Enstitüsü Yüksek lisans tezi

Ozan Bircan,2010, Kemane icrasında artikülasyon ve yay uygulamaları Haliç Üniversitesi Sosyal bilimler Enstitisü yüksek lisans tezi )

Mehmet Şimşek, 2013, Teke yöresi Burdur ili mahalli kemane icracılarının yöresel kemane çalım teknikleri, Haliç Üniversitesi / Sosyal Bilimler Enstitüsü Yüksek lisans tezi

\section{Kemanede çalım farklılıkları uslup tavırlar}

Yaptığımız inceleme ve tespitlere göre kemane üç farklı üslup ta çalındığı görülmektedir.

1- Geleneksel çalım tekniği. Yayın bir mızrap gibi kesik ve kısa çekilerek çalınması daha ziyade süslemenin trille yapılması kaydırma ve çarpmaların görülmesi.

Bu üsluptaki en büyük temsilcisi Salih Urhan

2- Kemanenin kemança gibi çalınması kemança- kemane arası çalım 
3- Kemanenin Geleneksel Türk sanat Müziği yaylı çalgıları gibi uzun ve bol glisando ile çalanlar popüler çalım üslubu da diyebiliriz. Çalgının ses tonuna yapılan efekt cihazlarıyla yapılan müdahalelerle kemanenin hangi yaylı çalgı ve hangi müzik disiplininde çalındığı anlaşılamamaktadır. Bu çalım üslubunun icracılarda yol gösterme, açış geleneksel doğaçlamanın yerini taksime bırakması en dikkat çekici unsurdur.

\section{Kemanede yöresel çalım tekniği ( tavır )}

Türk Halk Müziği icrasında çalım tekniği yöresel ezgi yapısı ve yöresel müzik cümleleri çok önemlidir. Açış, yol gösterme gibi serbest çalım şekillerinde icra edilecek eserin makamsal dizi karakteri dışında mutlaka yöresel müzik cümlelerine dikkat edilinilir.

Bağlama da olduğu gibi Kemanede de yöresel ezgilerden kaynaklanan farklı yay çekimleri görülmektedir.

Konya ve Silifke ezgilerinde kesik ve keskin yay kullanılır.

Teke Zortlatmalarında 9/16 çalımın ve Zeybek icralarında bağlamının mızrabıyla kemanın yayının birleştiği zaman zaman bağlamanın mızrabı gibi kısa yay zaman zamanda uzun bağlı yayların çekilerek ezginin icra edilir.

Orta Anadolu da ise yine bağlamanın kıvrak mırabı kemanede hissettirilir. Orta Anadolu geleneksel Keman çalım şeklinde icra edilir

Anadolu eskiden çok görülen dizde keman çalma tavrı bu gün genellikle Amasya Tokat Sivas Tuncel Malatya yörelerinde görülmektedir. Keman yayı çok uzun ve bağşlı değildir. Süslemeler genellikle tril şeklindedir.

Azerbaycan ezgilerinde çarpma kaydırma glisandolar daha fazla görülür.

Karadeniz'de ise bol trilli kısa kesik yay kullanılır.

\section{Kemane ile yapılan konser ve albüm çalışmaları}

Kabak kemane ile yapılan bir çok taş plak kaydı mevcuttur. Bu kayıtlarda genellikle mahalli sanatçıların çaldığ 1 halk ezgileri yer almaktadır. Emin Aldemir bir çok plak ve longplay albümlerinde kemane ile halk müziği sanatçılarına eşlik etmiştir.

1981 yılında Ankara radyosunda göreve başlayan İhsan Mendeş' in geleneksel kemane çalım tekniğinin üstüne getirdiği üslup kemanenin önünü açmıştır. Sanatçı halk müziği dışında farklı türde müziklere ve sanatçılara kemanesi ile eşlik etmiş, .bir ekol haline gelmiştir. Daha sonra yetişen pek çok kemane sanatçısında İhsan Mendeş etkisi görülmektedir.

Yeni kuşak kemane sanatçılarla icra tekniğinin üst düzeylere çıkması ve farklı müzik türlerinin de seslendirilmeye başlanılması ile kemanenin daha geniş kitleler tarafından tanınır ve sevilir hale gelmesini sağlamıştır. Bunun sonucu olarak ülkemizin hemen her yöresinde kemane çalan ve kemaneye ilgisi olan müzisyenlerin sayısının artmasına yol açmıştır. Son dönemlerde kemane sanatçılarının solist olduğu konserler ve dinletilerin başlamış olması, bu etkinliklere ilginin giderek artması umut verici bir gelişmedir. $\mathrm{Bu}$ ilgi ülkemiz kemane sanatçıları dışında yurt dışında popüler olan kemane ailesi içinde saydığımız kemança sanatçılarının da ülkemizde konser vermelerine sebep olmuştur. Tekfen Flarmoni orkestrası ile Azerbaycanlı kemança sanatçısı Adalet Vezirov, Aslan Hazreti'nin Amerikada yaşayan Azerbaycanlı kemança sanatçısı İmamyar Hasanov ile birlikte verdiği konser ve son dönem ülkemizde de popüler olan İsrailli sanatçı Mark Eliyahu seri konserleri ilk akla gelenlerdir.. 
Medya iletişim araçları vasıtasıyla bu gelişim başta Türk dünyasının olmak üzere yurtdışında da bir çok müzik adamının ilgisini çekmiştir. Azerbaycanlı kemança sanatçılarından kemaneye ilgileri yanında kemançayı kemane çalım şekliyle ve ezgileriyle çalmaya başlamaları da dikkat çekicidir.

Kabak kemane halk müziği orkestralarının dışında ki müzik grupları içinde yer almaya Moğollar grubu ile başlamıştır. 2000 li yıllarda Ege Üniversitesi Devlet Türk Musikisi Konservatuvarı Kabak kemane öğretim görevlisi Özgür Çelik 'in de yer aldığı Mecaz da bunlardan biridir. Özgür çelik kemanesi ile başta kendi okulunda olmak üzere bir çok konser vermiştir Uğur Önür " Mesel " adlı grupla bir çok ülkede konser vermiştir. TRT İzmir Radyosu Sanatçısı Cafer Nazlıbaş Feryadı Kemane adlı ilk albümünün tanıtım konserinin yanında Ankara, İzmir ve İstanbul 'da bir çok kez solo konser vermiştir.

Ülkemizde sadece enstrümantal olan içinde söz unsuru olmayan bir konser etkinliği maalesef yeterince ilgi çekmemektedir. Solo kemane konser ve dinletilerinde bu nedenle oyun havaları dışında sözlü halk ezgileri enstrümantal olarak çalınmış hatta zaman zaman vokal katkısı eklenmiştir.

Kemane-Kemança sanatçılarının yapmış olduğu albümlere baktığımızda iki çeşit albüm yapıldığı görülmektedir.

\section{1 - Sadece kemanenin solist olduğu enstrümantal albüm}

Muhsin Gurbani : Şenlik Regsi, Hazan Yeli

İhsan Mendeş : Efkar

Özgür Çelik: Öznağme

Göktuğ Çelik: Düşler ve Renkler - Ufak ufak

Cafer Nazlıbaş: Feryad-1 Kemane

\section{2 - Kemane sanatçısının çalıp okuduğu türkülerden oluşan içinde enstrümantal ezgilerinde olduğu karma albüm.}

Bayram Salman : Zeytin dalı

İrfan Gürdal : Atın Türküsü

Mehtap Demir : Anadolu kokusu, Ninniler - Anadolu ezgileriyle , Söyle Mehtap, Türkülerin senfonisi

Uğur Önür :Köy Havas1

Ülkemizde geleneksel çalgılar için orkestra eseri olarak uzun yıllar Ferit Alnar kanun konçertosu dışında eser üretilmemiş, ancak son dönemlerde yeni eserler üretilmeye başlanmıştır.

Geleneksel çalgılarımızdan bağlama, senfoni orkestrası eşliğinde çalınmış ayrıca klasik kemençe, ney ve kemane gibi çalgılar da orkestralar eşliğinde konserler verilmektedir.. Kemane sanatçıları Cafer Nazlıbaş ve Uğur Önür'ün Avustralya' da kemane ile orkestra eşliğinde konser vermesi kemanenin daha ileri seviyelere taşınacağının da habercisidir. Kemanenin Azerbaycan'daki kardeşi olan kemanca için orkestra eserleri, konçertolar varken halen bu çalgı için bir eser yazılmamıştır. Son dönemlerde yeni çalışmalarda genellikle halk 
ezgilerine orkestra düzenlemeleri yapılmasından öte yeni bir şey yoktur. Farklı tondaki kemaneler için şimdiye kadar bir parti yazımı gerçekleşmemiştir. TRT programlarında kullanılan bas kemane de aynı ezgiyi farklı oktavlardan seslendirmekten öteye gidememiştir. Ancak son dönemlerde orkestralar için halk ezgisi düzenleme yapanlarda bas kemane içinde parti yazdıkları görülmektedir. Aslında çello için yazılan bu partiler halk çalgıları orkestrasında bas kemane de çalabilir ifadesi ile bas kemane literatürde görülmeye başlamıştır.

İstanbul'da yaşayan Azerbaycan asıllı kemanca sanatçısı Arslan Hazreti çeşitli boyutlardaki 4 adet kemane veya kemanca ila konserler vermeye başlamış. Çalınan ezgileri de kendisi düzenlemiştir.

\section{Son söz}

Yaptığımız bu çalışma sonunda Iklı̆̆ ailesinden olan Azerbaycan ve İran Kemançasının dünyada tanınırlığı yanında Kemanenin de gitikçe tanınır olmaya başladığı görülmektedir. Artık Kemane yöresel çalgı dan ziyade tüm yörelerimizde bilinen ve çalınan bir çalgı hüviyetine bürünmüş tıpkı diğer Türk cumhuriyetlerinde olduğu gibi halk çalgıları içinde üst sıralara yerleşmiştir. Çalgı eğitimi veren yüksek öğretim kurumları ile kemane yapımcılarının birlikte yapacakları çalışmalar ve eğitimle kemane yapımcılığı bir düzene girmesi milli bir çalg1 da olması gereken ortak bir görünüm alması gerekmektedir. Iklı̆̆ ailesinden kullanılan diğer kardeş cumhuriyetleri ile yapılacak ortak çalışmalarla daha üst seviyede icra edileceği görülmektedir. Özellikle eğitim yaşının ilkokul seviyesine indirilmesi gerekmektedir. Anadolu güzel sanatlar liselerinde ivedilikle bu çalgının eğitimi ders olarak konulmalıdır. Sayıları gittikçe artan kemane eğitimi veren yüksek öğretim kurumlarından mezun olanlara da iş sahası açısından bu çok gereklidir.

Günümüzde bu okullardan mezun olan sanatçı adayları TRT ve Kültür Bakanlığının çok nadir olan kadrolarına girmeyi hayal bile edememekte formasyon alıp yaşamlarına müzik öğretmeni olarak devam etmektedirler. Belediyelerin kültür müdürlüklerinde ve halk eğitim merkezlerinde açılacak kadrolarla bu güzel milli çalgımızı icra eden sanatçılara istihdam sağlanabilir kanaatindeyiz.

TRT ve Kültür bakanlığı bünyesinde sadece kemane ile yapılacak konserlerinde bu çalgının tanınmasında faydalı olacağına inanıyoruz.

$\mathrm{Bu}$ çalışmada unuttuğumuz, gözden kaçırdığımız sanatçılar, yapımcılar ve eksiklerimiz olacaktır. Gittikçe artan akademik çalışmalar doğrultusunda yaptığımız bu çalışmanın yeni araştırmalara yardımcı olacağına temenni ediyoruz.

\section{Kaynakça}

1. Açın, Cafer. Enstrumanlarda denge ve oranlar, İstanbul 1994

2. Açın, Cafer. Organoloji ,İstanbul 1994

3. Açın, Yücel. Türk Halk Müziği yaylı sazlarından Kemane'nin doğuşu, yapımı ve ailesinin oluşması İstanbul Teknik Üniversitesi Sosyal Bilimler Enstitüsü Basılmamış yüksek lisans tezi. İstanbul,1993 
4. Akarçay, Aytaç. Türk Halk Müziği Sazlarının Sınıflandırılması, Kullanıldığı Yöreler ve türler

5. Aksoy, Bahattin. Avrupalı gezginlerin gözüyle Osmanlıda musiki Pan yayıncılık İstanbul2003

6. Ali Haytap Kulaboğa, Afyon Kocatepe Üniversitesi Devlet Konservatuvarı Öğretim Görevlisi Kişisel görüşme

7. Bardakçı, Murat. Ahmed Oğlu Şükrullah'ın Risalesi ve 15.yüzyıl Şark Musikisi Nazariyatı Pan Yayınları, İstanbul, 2011

8. Çelik Özgür Ege Üniversitesi Türk Musikisi Devlet Konservatuvarı Öğretim Görevlisi. Kişisel görüşme

9. Çelik Özgür Türk Dünyası'nda Üç Yaylı Çalgı: Kılkobız, Kamança ve Kabak Kemane Ege Üniversitesi Yayınları, İzmir 2010

10. Çelik Özgür, Bir kabak kemane yapım ustası: Halil Çelik, Halk Müziğinde Çalgılar Uluslararası Sempozyumu Bildirileri. İstanbul: Motif Vakfı Yayınları, 2009

11. Çolakoğlu, Gözde. Geleneksel çalgılardan orkestral tınıya doğru: Kemençe beşlemesi ve gadulka ailesi örneklemi. KTÜ 1. Uluslarası müzik araştırmları sempozyumu “Müzik ve Kültürel Doku’ Trabzon 2012

12. Değirmenci T., Eren B, Burdur'da kabak kemane yapımcılığı, ulusal pazarda yeri 1.Burdur sempozyumu bildiriler. Burdur 2007

13. Ereren, F. Orkestra, bağlama ve ses için Türküler 1,

14. Guliyev, O. Azerbaycan halk çalgı aletleri orkestri, işıg matbaası Bakü 1980

15. Gültekin, Şener. Gaziantep Üniversitesi Türk Musikisi Devlet Konservatuvarı Öğretim Görevlisi kişisel görüşme

16. Günay, Edip. Uçan, Ali. Çevreden Evrene Keman eğitimi. Dağarcık Yayınları. Ankara

17. Işık, T, S. Türkiyede Organoloji çalışmaları, Mukaddime dergisi, Mardin.2015

18. İmanova, Ofelya. Recebova, Rana Kemança Mektebi Şirvan neşr. Bakü 2005

19. Kadir Verim. İstanbul Teknik Üniversitesi Türk Musikisi Devlet Konservatuvarı Öğretim Görevlisi kişisel görüşme

20. Kamiloğlu, Ramazan. Ahmed Oğlu Şükrullah ve "Edvâr-1 Mûsikî" adlı eseri Ankara Üniversitesi Sosyal Bilimler Enstitüsü 2007

21. Kerimov, Hafiz, Kemança için Gam ve Etüdler Bakü 1991

22. Mahmut R. Gazimihal; Asya ve Anadolu Kaynaklarında IKLIĞ Ses ve tel birliği yayınları. Ankara 1958

23. Mirişli, Ramiz Mkrtıçev, A. Kemança mektebi Azerbaycan Devlet Neşriyatı. bakü. 1970

24. Ozan Bircan. Haliç Üniversitesi Türk Musikisi Devlet Konservatuvarı Öğretim Görevlisi. Kişisel görüşme

25. Ögel, Bahaddin, Kültür tarihine giriş 9. cilt Ankara,1987

26. Özcan T. A, Iklı̆̆-Rebap-Kemençe-Keman, Yaylı Çalgı Evrimi ve Müziği MÜ. Sosyal.Bilimler.Enstitisü. Yüksek Lisans Tezi. 2008

27. Paşmakçı, Yücel. Haliç Üniversitesi Konservatuvarı Öğretim Görevlisi. Kişisel görüşme. 
28. Rahmetzade, Evez Kemança üzre bilgi. Tebriz . 1954

29. Rehmetov, E. Bakü Azerbaycan halk çalgı aletleri ve onların orkestradaki yeri, Bakü,1980

30. Şener, Gültekin. Türk halk müziği yaylı sazlarından kemane'nin yapısı -pozisyon problemleri ve eğitimi.İstanbul 1994

31. Timur Eşigül. Ordu Üniversitesi Türk Musikisi Devlet Konservatuvarı Öğretim Görevlisi. Kişisel görüşme

32. Urhan, Salih Kemane Metodu, İzmir 2014

33. Uğur Önür. TRT İstanbul Radyosu Kemane Sanatçısı kişisel görüşme

34. Uslu, Recep, Selçuklu Topraklarında Müzik, Konya Valiliği İl Kültür ve Turizm Mdürülüğü yayınları Konya 1015 